John Carroll University Carroll Collected

History

2006

\title{
Arbeitspflicht in Postwar Vienna: Punishing Nazis vs. Expediting Reconstruction, 1945-48
}

Matthew P. Berg

John Carroll University, mberg@jcu.edu

Follow this and additional works at: http:// collected.jcu.edu/hist-facpub

Part of the European History Commons

\section{Recommended Citation}

Berg, Matthew P., "Arbeitspflicht in Postwar Vienna: Punishing Nazis vs. Expediting Reconstruction, 1945-48" (2006). History. 39. http://collected.jcu.edu/hist-facpub/39

This Article is brought to you for free and open access by Carroll Collected. It has been accepted for inclusion in History by an authorized administrator of Carroll Collected. For more information, please contact connell@jcu.edu. 


\section{Arbeitspflicht in Postwar Vienna: Punishing Nazis vs. Expediting Reconstruction, 1945-48 \\ Matthew Paul Berg}

Even before the war in Europe ended formally on 8 May 1945, there could be no serious misconceptions-either among defeated and liberated peoples or among the victorious Allied powers-as to how complex the challenges of reconstructing physical infrastructure and social networks would be.1 This was particularly true in urban areas within what had been Germany's 1938 borders, where the impact of air raids had reduced many areas to rubble and had damaged the rail and road connections that supplied foodstuffs and other necessities. In Berlin and other cities, images of people clearing debris from lunar landscapes dominated the popular imagination in the late 1940s and over the following decades. Indeed, when images of immediate postwar reconstruction have been invoked, it would appear as if there existed a heroic, unbroken connection between the initiative of these largely female volunteers (Trummerfrauen) and the economic miracle associated overwhelmingly with largely male labor in West Germany a decade later. If a remarkable preparedness to come to terms with the exigencies of the present manifested itself during the initial postwar months, historians have subsequently offered insights into how problematic a consistent and thorough confrontation with the Nazi past proved to be during the later 1940s and beyond. The tension between a fundamental readiness to engage in physical reconstruction and a widespread resistance to addressing ideological reorientation has been explored in various ways in studies published since the late 1980s.2

Investigation into postwar reconstruction in Austria reveals conditions as complex in their own right, even though the damage suffered in the former Ostmark was nowhere as comprehensive as in much of Germany-notwithstanding significant destruction wrought upon sections of Vienna, Linz, Wiener Neustadt, and a handful of other locations. These complexities stem in large measure from the tension between Austria's status as the "first victim of Nazi aggression," as designated in the Moscow Declaration of 1943, which allowed one to speak of "liberation" in April/May 1945, and Austria's status as a land of (co-)perpetrators to be defeated, denazified, and controlled, which evoked the trope of "occupation:' The repression of the latter and emphasis on the former in the Austrian Second Republic dominated popular and scholarly attitudes toward the Nazi past well into the mid 1980s. At that point, the Waldheim Affair and the emergence of Jorg Haider on the right of the political spectrum prompted a number of politicians, historians, politi- cal scientists, literary figures, and journalists to press for meaningful Vergangenheitewültigung (coming to terms with the past) through serious academic inquiry and public discourse.

In the wake of popular reactions to Waldheim and Haider, a host of studies treating a range of long-neglected or underinvestigated themes in contemporary Austrian history and identity have begun to advance our understanding of Vergangenheitsbewültigung in the Second Republic, particularly during the earlier postwar period.3 Moreover, as archival records have become increasingly accessible in recent years, new works have taken up immediate post-conflict Austrian reconstruction on the regional and municipal levels. Such studies either emphasize denazification as a cardinal feature of reconstruction efforts, or explore the process of removing rubble and rebuilding as the 
necessary, cathartic moment in the creation of a new-or renewed-sense of community. Still other historians have taken up the subject of urban everyday life concerns as Austrians struggled to create conditions of normality during the ten-year period of fourpower occupation.4 These contributions have shed new light on fundamental elements of postwar reconstruction, but a systematic and integrative approach to these two major themes has yet to be written.

This essay offers a step in precisely that direction. It focuses upon the urban milieu of immediate postwar Vienna as a site where authorities sought to establish a specific linkage of the political, social, and economic dimensions of denazification with the initial stages of physical reconstruction-a kind of "expiation through labor"-in the interest of reestablishing an orderly, democratic political culture in the former Social Democratic stronghold. Initially the product of mayoral decree, yet sanctioned as federal law by the summer of 1946, labor service shamed and stigmatized, but also aroused indignant feelings of victimization among many of those assigned to perform it. This study explores the ways in which the exigencies of debris removal and basic infrastructure repair preoccupied municipal officials and federal politicians, and the impact that labor service had on ex-Nazis and those required to work beside them. At the same time, it takes into consideration broader Austrian developments, including the relative impact of federal labor service legislation throughout the Second Republic and the influence of the occupation powers and the Marshall Plan on mandatory, reconstruction-oriented labor.

While recent years have witnessed an increased interest in Austrian "peripheries" (Linz, Salzburg, Graz, or smaller communities) at the expense of the Viennese "core: this essay points to the significance of revisiting developments in the capital immediately after World War II. The first free elections held after the Third Reich's collapse restored Vienna's status as a Social Democratic city, yet a large population of former Nazis resided in the city, 5 including many erstwhile Social Democrats who had sought affiliation with the NSDAP after the Anschluss. Pragmatic reintegration of lesser Nazis or wholesale exclusion of those who had either found an ideological home or opportunistic refuge in the Nazi camp became central considerations for the heirs to Red Vienna's administrative legacy. Postwar Social Democratic city officials could ill afford to be considered soft on fascism by either foreign occupiers or the more vocal antifascists among their own constituency. However, a premium placed on the technical or administrative expertise that many former Nazis possessed and the political/legal ground rules of a new democratic republic limited the extent to which municipal authorities might opt for conditional amnesty or punishment.

The above examples, explored in depth throughout this essay, provide a brief introduction to those tensions prevalent in postwar Vienna. My intention is to strike a working balance between decisions taken by city officials and federal politicians on the one hand, and their impact on the life circumstances of those assigned to reconstruction labor on the other. The context of an urban community entering into a stage of unprecedented post-conflict transformation affords us fertile ground to explore this interface, and a wide range of largely neglected archival sources lend themselves to such an endeavor.

The first section of this essay conveys a sense for the physical damage suffered by the city and its consequences for residents' lives from mid 1945 into early 1946. It takes up the matter of Soviet organization of forced labor for initial reconstruction tasks, both 
to remedy Vienna's plight and to benefit the Red Army. It also explores the conceptualization and implementation of mayoral decrees concerning emergency labor service for what I call "first stage" reconstruction (repair of basic infrastructures such as gas, electrical, and water lines; repair of streets, sewage lines, and railroad lines; removal of rubble from public squares, public buildings, and damaged or destroyed privately owned structures) and the reactions of those affected by it (ex-Nazis, black marketers, slackers, the unemployed and underemployed). The second section examines features of the 1946 federal labor service law (Arbeitspflichtgesetz), its implementation, and representative responses from Viennese residents subjected to labor service. Renewed in 1947 and 1948, the Arbeitspflichtgesetz reflected both the pressing demands of first-stage reconstruction and the evolution of denazification legislation. The third section assesses the law's efficacy between 1946 and 1948 in the context of Austria-wide developments, specific Viennese circumstances, and the introduction of the Marshall Plan and Cold War tensions. I argue that mandatory labor service in Vienna contributed only marginally to the success of early reconstruction efforts, so that by mid 1947 through 1948 it brought negligible benefits. As the 1949 reenfranchisement of those deemed "less-implicated" Nazis drew closer and first-stage reconstruction tasks had been largely accomplished, labor service was abolished parallel to the amnesty granted to the vast majority of former Nazis.

Key elements of the theoretical groundwork for a synthetic approach to denazification and reconstruction have been laid by historians such as Ela Hornung and Margit Sturm, Hans-Georg Heinrich, and Siegfried Matti. For example, Heinrich has argued that political identity and political culture in Vienna have always been determined more by the social and cultural than either the national or political. This phenomenon had its origins in the "charismatic power of ... the imperial court, whose presence shaped the entirety of Viennese society.... Proximity and access to the court determined the social and thus the economic position of groups and individuals."6 Heinrich's analysis focuses primarily on interwar Red Vienna, but his conclusion is no less relevant for the Second Republic, even as early as the immediate postwar period. "Power structures had indeed changed their form since the end of the monarchy;' he notes, "but in essence their effects remained entirely comparable. One could say that the emperor took up new quarters in city hall. The 'court' was the municipal council, and the population was entirely dependent upon the governing party for access, even to the most minute ramifications of daily life:' 7

As Viennese, together with initially Soviet and later four-power occupation forces, began to establish a semblance of postwar order, district and central municipal administrative power concentrated itself largely in Social Democratic hands. This was not surprising, given the strength of the city's Social Democratic political machine between 1919 and 1934. Yet it is remarkable that the Social Democratic municipal organization reemerged with such speed and resiliency in the late spring and summer of 1945. Four years of a repressive, indigenous authoritarian government had driven Viennese Social Democrats underground or into exile, and the Nazi regime demonstrated an even more brutal intolerance toward them-even as it offered itself as a new home for many who were prepared to change their political colors. Siegfried Matti accounts for this strength and resiliency when he remarks that the Viennese Social Democratic organization "had discovered in its system of 'ward heelers' (Vertrauensmünner and Vertrauensfrauen) a 
unique model for combining highly professionalized and bureaucratic party structures with face-to-face interactions among its members. These party operatives were, to use Antonio Gramsci's terminology, 'organic intellectuals' who were able to straddle the line separating the logic of modern organizational apparatuses from the logic of everyday life. 8

Election results in November 1945 evinced the strength of the party organization and its appeal to voters. In Vienna's twenty-six districts (the total changed with redistricting in 1954), the Social Democrats controlled all but six outright during the first several postwar years, and over subsequent decades this dominance did not change significantly. Vertrauensleute represented the party's specific interests as party officials, and the Bezirksvorsteher retained their high-profile Social Democratic identities as city district administrators at the local level. However, it was not uncommon for district administrators to exercise responsibilities as "ward heelers" as well, or to have emerged to political prominence in this capacity; such individuals likely understood the sentiments of their party colleagues/constituents far more intimately than municipal bureaucrats might have. This, in turn, could contribute to certain tensions between the city administration and individual district officials. For example, the latter more often than not embraced the strict antifascist measures handed down from city hall prior to the introduction of denazification legislation and readily implemented them as obvious and natural. Upon the introduction of such legislation, however, the municipal administration's insistence upon adherence to the new republic's spirit of democratic republican legality could be perceived as insufficiently antifascist by Bezirksvorsteher and Social Democratic Vertrauensleute. It was at these moments that those subjected to labor service issued pleas for redress directly to the mayor's office over the heads of "oppressive" district administrators. The tone of their supplications bears out Heinrich's observation of a shift in the locus of power from the imperial court to city hall.

\section{Confronting Former Nazis and War-Related Destruction in Vienna, May-December 1945}

Although Vienna did not suffer the scale of destruction absorbed by Berlin, Dresden, Hamburg, or other German-speaking population centers, the city by no means emerged unscathed. Combat during the final weeks of the war in Austria inflicted structural damage on Vienna's historic city center, as well as parts of its eastern, southeastern, and northern districts. Moreover, the frequency and intensity of Allied bombing reached unprecedented levels during the later part of 1944 as air raids struck the city's rail centers and Danube shipping installations in particular. Of course, many bombs wrought serious damage-or wholesale destruction-upon housing stock and public buildings. The municipal administration estimated that 41 percent of all buildings in the Gemeinde Wien suffered some form of damage-that is, either destroyed completely, rendered largely uninhabitable, or in need of significant repair.9 An investigation completed in late 1945 revealed that 36,851 structures had been destroyed-including private as well as municipally owned and administered apartment houses, in addition to city and state administrative buildings-while another 50,024 additional edifices in these categories had suffered significant damage.10 The Municipal Housing Office (Wohnungsamt) estimated that approximately 100,000 housing units (single family houses and individual apartments) had been destroyed or rendered otherwise 
uninhabitable-a figure that corresponded roughly to the total number of lost or damaged housing units in Linz, Salzburg, Innsbruck, and Bregenz combined.11 Subsequent investigations identified far-reaching damage to Vienna's transportation network through the destruction of roadways and the bombing of the southern, western, and northern railway stations and hundreds of kilometers of track and some 135 bridges (primarily over the Danube and Wienfluss). Authorities estimated that some 850,000 cubic meters of rubble littered the city in April 1945-a quantity that increased as damaged buildings subsequently collapsed or were torn down to eliminate safety hazards and to clear space for new construction in the later 1940s.12 Moreover, the city's extensive sewage network suffered damage at almost 1,700 locations.13

Efforts to clear rubble and debris and to bury bodies during the first month of occupation in Vienna proceeded generally at the impetus of the Soviet occupation forces, and even then in a seemingly haphazard fashion. Prevailing practice took the form of stationing soldiers at the corners of busy streets in order to detain pedestrians for labor service. The behavior of Soviet troops was less a question of wanton intimidation than an effort to secure labor for reconstruction during a period when the municipal departments had ceased to function cohesively. In an effort to regulate the deployment of workers systematically, the then -provisional Social Democratic mayor Theodor Korner urged the various Viennese district administrators (Bezirksvorsteher) in a note of 7 May 1945 to inform Soviet authorities which individuals or groups would be available for work details. Korner's decision took three factors into consideration. First, he maintained that the health of potential workers should be a central concern in selection. Second, individuals already employed in sectors important to the reconstruction effort should not be removed from their workshops or firms if their labor contributed meaningfully to reconstruction. Finally, in the interest of minimizing friction between Red Army forces and the civil population, Korner maintained that the oppressive arbitrariness of selection, as perceived by the Viennese, should be abolished.14 In some cases individuals subjected to "wild requisitioning" had disappeared for several days, during which they were engaged in building bridges and creating roads, driving animals, and a variety of clean-up tasks under extremely taxing circumstances.15 Korner's decree, issued with the blessings of the Soviet commandant, did not make labor service any more popular among city residents. Nonetheless, it introduced a critical measure of order and established the municipal authority as a negotiating partner with the Allies and as an advocate for Vienna's population. Arbitrary detainment at the hands of Soviet troops did not cease altogether, 16 but its frequency diminished considerably.

The second-and in some respects more decisive-policy shift concerning labor allocation followed the introduction of the Verbotsgesetz (Prohibition Law). According to this federal legislation passed by the provisional government with Allied Council approval on 8 May 1945,17 individuals with an established primary residence on Austrian territory between 1 July 1933 and 27 April 1945 who had become Nazi party members, members of its military formations (the SS, SA, or Nazi military officers' association), or had been leading functionaries in other Nazi organizations or in district or local administration, were required to register with Austrian and Allied authorities. The total number of those affected reached approximately 536,000. These people found themselves deprived of the rights to vote and hold political office and were excluded from a range of employment positions in the public and private sectors. Between May 1945 and the 
revision of denazification legislation in 1946/47, individuals required to register could, in limited cases, become members of one of the three recognized democratic political parties: the Austrian Communist Party (Kommunistische Partei Osterreichs, KPO), the Austrian People's Party (Osterreichische Volkspartei, OVP), or the Austrian Socialist Party (Sozialistische Partei Osterreichs, SP0).18 Austrians over eighteen who had joined the NSDAP between 1 July 1933, when the Nazi Party was outlawed by the authoritarian Catholic-conservative regime, and the 13 March 1938 Anschluss-the so-called Illegalencould be charged with treason and sentenced to between five and ten years imprisonment. For many antifascists, this significant number of former Nazis (widely referred to as Ehemalige) represented a logical labor pool for basic reconstruction tasks that, in the weeks since the collapse of the Third Reich's authority, had not been utilized widely or consistently.

In his position as mayor of the city and governor of the province of Vienna, Korneralong with other provisional provincial governors in eastern Austria-received notification in early June 1945 that the Soviet occupation force had insisted upon the allocation of labor to resolve specific reconstruction problems. This would be accomplished in cooperation with Franz Hanner (KPO), provisional state secretary for the interior, who assumed the responsibility of systematizing the introduction of Ehemalige into labor service. Tasks to which they would be directed included addressing sanitary conditions in order to combat the spread of disease, clearance and repair of damage to transportation networks, and restoration of all the various public institutions to working order. Insofar as it was possible, the Austrian Provisional Government and the Soviets favored employment of former Nazis, using the recently introduced denazification legislation as a guide to identifying potential laborers. The law stated:

In the first instance, the so-called Illegalen as per $\S 10$ and $\S 11$ under the constitutional law [of 8 May 1945], those people who were members of the SS, functionaries within the party or its related associations, leaders of paramilitary groups at the rank of Untersturmführer or its equivalent and higher, and finally anyone who did not belong to the above circles, but who behaved in a fashion that violated basic principles of humanity for personal gain or other objectionable motives are to be enlisted [for labor].

Members of the [National Socialist] party and its associations and party applicants who did not hold positions of authority are to be enlisted ... in those cases when either sufficient numbers of heavily implicated [belastet] National Socialists are not available, or such individuals cannot verify regular employment.19

While a punitive consideration to summoning the Illegalen and the otherwise heavily implicated Ehemaligen undoubtedly existed, Austrian authorities determined that, in order to distinguish the new Austrian authorities from the Nazi regime, compulsory labor service for reconstruction could not violate basic human rights. For instance, people under age sixteen or over sixty-five were not required to appear for work details, nor were those who could demonstrate that their physical conditions prevented them from engaging in difficult manual labor. Moreover, the Ehemaligen were not, under any circumstances, to be singled out with special symbols or designations (for example, a swastika on their clothing); this was deemed incompatible with the new, democratic Austria's protection of fundamental human dignity.20 Further, the office of the Provisional State Secretary for Social Administration (soziale Verwaltung) had insisted that former Nazis compelled to engage in labor service would be compensated at the 
going daily rate for workers employed in comparable tasks.21 In order to prioritize labor allocation, Ehemalige would be required to provide provincial labor offices (Landesarbeitsümter) with proof of employment; in instances of noncompliance, Austrian authorities could withhold ration cards.22 Unemployed Belastete and lessimplicated Ehemalige would be inducted into labor service first, followed by their former party comrades whose jobs were deemed of little or no importance to reconstruction efforts. 23

Despite this new directive, progress toward amassing sufficient labor for basic reconstruction projects proceeded haltingly during the summer of 1945. Several factors are obvious. Registration of Nazis with the Austrian authorities and occupation regimes required considerable personnel. Questionnaires had to be vetted, supporting documentation reviewed, and corroborating evidence verified before potential reconstruction laborers could be identified. Further, in Vienna-as in the rest of Austria-the vast majority of local, provincial, and federal civil servants had been NSDAP members. To purge the bureaucracy and replace Nazis with reliable antifascists would require more than just the several weeks following the cessation of hostilities. Korner did not sympathize with National Socialists in the least, but he feared that a purge of all party members and member candidates (Parteimitglieder and Parteianwürter) from the municipal bureaucracy would introduce administrative paralysis, 24 with implications for the various authorities involved in the recruitment and allocation of workers, including the municipal police force (Polizeidirektion Wien), the Landesarbeitsamt, and those municipal departments (Magistratsabteilungen) responsible for priority reconstruction.

Beyond these structural difficulties lay a different kind of problem, however. After long years of war and its accompanying hardships, many Viennese wanted nothing more than to relax and try to enjoy the coming of the peace to the extent that circumstances permitted. As the weather turned warm and sunny, the newspaper Neues Osterreich commented bitterly: "[R]ather than dedicate themselves to the far more important tasks of rebuilding our home- land[,]" large crowds began to congregate daily along the banks of the Danube. "[T] his will not do, of course.... It cannot be expected of working people ... that they support non-working people through their labor. Thus, it would be most welcome if ... food ration cards were only distributed to those willing to work.... If we all did the same as the summer sunbathers along the Danube, then we will all go to the dogs together:' 25 Not surprisingly, Neues Osterreich added Schlurfs to the list of those social forces who acted as a brake upon reconstruction initiatives. These primarily young, ablebodied male "slackers" preferred to congregate in coffee houses, dance halls, and cabarets whenever possible and maintained themselves through black market activity rather than through legitimate work at necessary tasks.26

By August 1945 it had become clear to Viennese municipal authorities, the Austrian provisional government, and all four Allied occupation powers that measures to jump-start reconstruction work had done little to meet even the most modest expectations. This prompted Korner to secure federal and four-power support to issue a public summons for the employment of men and women with a permanent residence in Vienna, both Ehemalige and non-Nazi alike, in emergency labor service (Notstandsarbeit) during the month of September. Under the categories of Illegalen and Belasteten ( $\S 4$ and $\S 12$ of the Verbotsgesetz from 8 May 1945, respectively), unemployed males between the ages of sixteen and sixty-five and women between fifteen and fifty- 
five would complete one hundred and twenty hours of labor service. For lesser Nazis and anyone not engaged in work deemed essential to reconstruction, unemployed males between the ages of fifteen and fifty and women between sixteen and forty would fulfill a total of sixty hours-forty hours if they still attended school. Those who worked full-time in sectors not considered vital for reconstruction would complete sixteen hours, but thirty-two hours if they belonged to the circles designated in $\S 4$ or $\S 12$. All workers would enjoy both health and accident insurance, provided by the city of Vienna, throughout the period of their employment. Those attempting to shirk this responsibility could reckon with a reduction in-or even revocation of-ration cards for the four-week period of emergency labor service.27 The Korner decree held out the possibility of exemption from labor service in very specific cases. These included:

- pregnant or nursing women who were solely responsible for running their households, as long as they had at least one child younger than ten years;

- politically or racially persecuted concentration camp inmates, as well as their mothers and wives, provided that they had never belonged to the groups identified in $\S 4$ and $\S 12$;

- clergymen, nuns, doctors, dentists, midwives, and civil servants (white or blue collar);

- people with war-related injuries (from either 1914-18 or 1939-45) belonging to the highest three classifications of disability.28

Posters affixed to kiosks throughout the city announced the terms of Notstandsarbeit; administrative officials in each district were responsible for conveying this information to residents, either by entrusting local political party organizations with further dissemination or requesting that superintendents in privately and municipally owned apartment buildings post the decree conspicuously. In preparation for the introduction of Notstandsarbeit, local officials compiled house lists for the Landesarbeitsamt and district police stations that included all pertinent data for every adult resident at each address.29 Municipal authorities in each district then posted a complete list of those required to enter into labor service as well as the duration of individual work commitments at a series of registration stations (Meldestellen). Responsibility lay with Viennese residents to check the list at their local Meldestelle to determine if they owed labor service.

Participants' responses to the Notstandsarbeit varied. On the whole, there are no indications that the majority of those affected sought to avoid September work details, however. Indeed, this may have been related in large measure to the linkage of ration card distribution with fulfillment of labor service; few could have afforded to exist from black market activity at a comfortable level for any sustained period. Moreover, fear of arrest for noncompliance, socialization to respect existing authorities, or a genuine desire to somehow "make good" to Austrian society for having played a role-however small-in the Nazi system may also have contributed to compliance. All the same, it would seem that many people required to work did not do so with great effectiveness or overwhelming zeal. This appears to have been the result of several factors. A severe shortage of backhoes and trucks to assist in loading and removing rubble and limited fuel to power them hampered efforts; a modest number of wagons, drawn by invariably lean and hungry horses, did little to make up for the shortage of mechanized support. Indeed, as one district police commissioner observed: "[W]ithout the support of Russian occupation authorities, where possible, the rubble removal effort would be condemned to total failure."30 Also factoring into the rather limited productivity for the September Arbeitseinsatz was the absence of productivity quotas-that is, a specific number of cubic 
meters of rubble to be moved per hour, contingent upon age or gender. Any such mandate would have smacked of the kind of authoritarianism that officials were determined to avoid at all costs. Moreover, among the Viennese soldiers held in Allied prisoner of war camps and unavailable for Notstandsarbeit were hundreds, if not thousands, of young and reasonably able-bodied men who would have qualified on the basis of unemployment or according to $\S 4$ or $\S 12$ of the Verbotsgesetz. Even if ample labor power could have been drawn upon, the average Viennese lacked the physical energy to work productively on a sustained basis; many people suffered from malnutrition and its associated maladies, as well as from debilitating illnesses such as tuberculosis.31 Average ration cards allowed for approximately 1,200 calories per day through the summer and early autumn-hardly a diet that allowed for sustained heavy physical exertion, even if one could supplement one's nutritional intake with foodstuffs from private gardens or illegal trade, or secure the modest 420 calorie supplement for engaging in demanding, reconstruction-oriented labor.32 Finally, just five months after the war's end, the municipal bureaucracy had yet to achieve a consistently high level of administrative efficiency due to personnel shortages linked to the large-scale dismissal of Nazis. Further impeding efficiency was the occasional political backlash and administrative instability related to the reinstatement and redismissal of a number of "lesser Nazis" (die Minderbelasteten)-that is, those whose status as Parteimitglieder or Parteianwürter did not place them under the restrictive clauses of the Verbotsgesetz.33

Some un- or underemployed Viennese embraced Notstandsarbeit, however. Such individuals-often self-identified as Social Democrats, but not exclusively so34 -considered it a vital expression of civic pride. For them labor service represented an opportunity to contribute to the restoration of the city's luster and its functioning infrastructure. Far more frequently, however, the archival record reveals cases of individual Viennese pleading extenuating circumstances to gain exemption from the September Arbeitseinsatz.

Whether or not Viennese citizens had become National Socialists, the manner in which they addressed the mayor as supplicants offers insight into everyday concerns, both material and health-related, during the immediate postwar period, as well as their justifications for either participating in or distancing themselves from the Nazi system. In one instance, a young woman of twenty-five protested that she was assigned one hundred and twenty hours of labor service-the maximum under Korner's decree. Friederike's sixty-two-year-old father, a World War I veteran with 50 percent disability from an unspecified service-related lung ailment, had allegedly been enrolled automatically in the ranks of the NSDAP in 1941 because of his work with the NS War Victims' Association. He claimed never to have been politically active. Because Korner's edict specified that those who could not work would have to provide an able-bodied family member who had behaved openly as a Nazi ("die sich offenkundig betatigt haben") in their place, Frau S., who insisted that she had neither been a Parteimitglied nor politically active in any way, was nonetheless ordered to fulfill her father's labor obligation. Her plea to Korner emphasized that her 'existence would be seriously endangered if [she] had to complete the 120 hours in one month;' for S. needed all her time to work two jobs to support her father and herself. This case found its way to the mayor's office (Bürgermeisteramt) for review, where experts deemed that municipal officials would have acted in contradiction to the law if the woman had, indeed, never been affiliated with the NSDAP or behaved in a fashion that supported the regime. Subsequent consultation between municipal 
authorities and the responsible district administrator (Herr Hajek of Wien-Rudolfsheim) resulted in the cancellation of Frau S's service requirement.35

If individual Viennese under the imperial, interwar republican, Fatherland Front, or Nazi regimes had understood that authority carried with it the responsibility to care for 'decent, lawabiding citizens;' the new municipal government also recognized the importance of administering the city on behalf of citizens in a fashion consistent with a new, democratic-republican Rechtsstaat. A particularly telling case is that of the Arbeitseinsatz in the district Wien-Leopoldstadt. In October 1945, representatives of the Association of Construction Firms notified the Landesarbeitsamt that district officials in Leopoldstadt had compelled private construction workers to log more than the thirty-two hours required of most engaged in the Arbeitseinsatz. Many had been forced to work as many as one hundred and fifty hours during September-a violation of the law and of their rights-with repercussions for the firms at which these people were employed. As a result, the association's representatives requested that the Landesarbeitsamt inform the police inspector responsible for monitoring the Arbeitseinsatz in Leopoldstadt of rampant violations. Korner's office received notification, and the situation was monitored from that point forward.36 Because of the extensive damage in Leopoldstadt, it appears to have been an "unwritten rule" among district officials that more labor would be exacted from their residents than stipulated in Korner's decree.37

Another striking example of the city government's commitment to the letter of the law on behalf of citizens is that of a graphic artist, Frau Hedwig S. from WienAlsergrund, a non-Nazi who found her name listed at her local Meldestelle on 21 September. She reported the next day and promptly asked for a medical examination from municipal health officials. Frau S. claimed to have experienced a middle ear operation, a kidney infection, removal of her tonsils, and scarlet fever over the previous several months; as a result of these maladies she had suffered anemia, exhaustion, and fainting spells. Herr R., the official on duty at the Meldestelle, replied that he could see to it that she had an easy desk job in the office, "for he already knew what sort of expert opinion the public health administration doctor would issue."38 Frau S. began working at the Meldestelle, but reported that in the process of organizing the labor exemption forms of Nazis and non-Nazis in the district, she noticed a physician's finding that "even National Socialists were excused from their labor duty because they were nineteen or twenty kilos below their normal weight (my weight was the same, actually twenty-one kilos below normal) without other mitigating health issues."39 Frau S. brought this information to the attention of Herr R., insisting that she too wished to avail herself of an official health examination. He responded with a torrent of threats and personal insultsincluding the remark that Frau S's profession was "worthless"-and referred her to a female doctor with the observation that he was "sending along a woman who didn't want to work:' Without bothering to examine her, the physician concluded that she was fit enough to fulfill her sixteen-hour requirement with light work. Frau S. drew a parallel between methods employed under the Third Reich and her own recent treatment: "Yesterday I experienced that there are elements within the public service of Austrian democracy who seem determined to outstrip [officials in] the earlier National Socialist labor offices and public health positions. Formerly one was declared an enemy of the state if one raised objections. I live as a free, unsullied citizen in a democratic state. Must I accept genuinely terroristic and personally insulting treatment because I dared politely 
and matter-of-factly to insist upon the exercise of my legal right that is afforded to citizens who are subject to punishment [under the Verbotsgesetz]?" In the end, Frau S. decided that she would complete her sixteen hours of labor service rather than risk the loss of her ration cards, but she remarked bitterly that "this sort of allocation of labor power cannot be in the interest of the Austrian political leadership:' 40 She received an invitation to visit the Magistratsdirektion to discuss the case. However, those who fell under the Verbotsgesetz and were unable to present extraordinary extenuating circumstances or confirm alleged ill health would find the Rathaus doors closed to them. 41

Between April and November 1945, officials employed in various capacities at the district level were overwhelmingly Social Democrats or Communists who had been harassed or otherwise victimized at the hands of National Socialist security officials. Given their antifascist credentials, municipal and district authorities considered them the most politically reliable people to replace former Nazis in positions of responsibility. Perhaps not surprisingly, in a number of cases these individuals violated legal principles in their zeal to accelerate the tempo of early reconstruction work and, where possible, to visit a form of retribution on National Socialists, their sympathizers, or those whom they perceived to be malingerers. This clashed with the efforts of municipal officials at the highest levels to champion the basic human dignity and legal rights of all citizens, including former Nazis. Although these individuals generally worked conscientiously within the framework of denazification legislation, they were also prepared to handle former Nazis pragmatically where conducive to promoting efficient administration. Where such decisions became known, they met with criticism from vocal antifascists in the district administrations and members of the citizenry, however. A particularly revealing example is that of Herr K., a Social Democrat from Wien-Penzing. Herr K. wrote to Mayor Korner as a concerned party comrade that "the Arbeitseinsatzleiter in the fourteenth district is a registered Nazi named Z. As a Socialist who has belonged to the party for decades, I find it disgraceful that a leading position in our Red Vienna can be given to a Nazi, against whom neither dismissal nor complaint is possible." 42 An investigation led the Magistratsdirektor to conclude that "Z. was never with the NSDAP, rather a contributing member to one of its organizations for only a short time. Thus he is not required to register on the denazification list.... The Landesarbeitsamt has taken into consideration Z.'s excellent work and therefore there is no occasion to remove him from his post:'43

In another case, an agricultural specialist in the municipal administration, Herr Diplomingenieur Emmerich F. was considered so valuable for coordination of the harvest in Vienna's outlying districts that he was permitted to defer his mandatory labor service for three months, even though he was known as a former NSDAP member in his home district ofWien-Floridsdorf.44 His work requirement would have arguably been far more physically taxing if performed when originally scheduled; after several weeks of concentrated Arbeitseinsatz, large reconstruction projects would have often been followed by less arduous follow-up tasks, to the benefit of individuals such as Herr F. who enjoyed deferments.

The case of Adolfine G. offers a final illustration of municipal commitment to the letter of the law, this time to the benefit of a person who had been a notorious Nazi and had earned the enmity of her antifascist neighbors. Although obliged to perform 
September labor service, Frau G. sent her young apprentices to fulfill her labor shifts, which involved particularly strenuous rubble removal. The KP newspaper Die Osterreichiche Volksstimme broke the story in its 11 October edition. Frau G. claimed that the apprentices, Fraulein T. and Fraulein H., had been willing to do the work, and Frau G. did not want to be absent from her business during an anticipated inspection. The district administrator for Wien-Ottakring initiated an investigation that resulted in a recommendation for disciplinary action-the Frau G. case had created bad blood within the district. However, the Magistratsdirektion noted that as vexing as Frau G.'s behavior was, it "did not, indeed, involve a punishable set of circumstances" under the terms of Korner's proclamation; officials at the various Meldestellen for labor service would have to be more vigilant in the future. 45

Bureaucratic confusion and the behavior of overzealous antifascists notwithstanding, Arbeitseinsatz did not bear any similarity to methods employed under the Third Reich. Both former Nazis caught up in punitive denazification measures and "untainted" Viennese affected by the compulsory features of reconstruction could appeal to the Rathaus to preserve legality against arbitrariness and could generally expect redress. To be sure, what the archival record cannot reveal is the extent to which individual supplicants treated unfairly by bureaucrats were too intimidated or fatalistic to register complaints with the Burgermeisteramt or with the Magistratsdirektion. On the other hand, if critics within the Viennese bureaucracy-or the broader population-felt confused by or dissatisfied with decisions taken in the Rathaus, they were hard pressed to make the case that the administration treated former Nazis or shirkers with anything resembling nonchalant leniency.

\section{Mandating Labor Service: Toward the 1946 Arbeitspflichtgesetz}

Given the above considerations, Korner's September Aufruf proved insufficient to catalyze a profound or an immediate improvement in the physical condition of the city. Moreover, by its very nature it was not designed to stimulate a sustained reconstruction effort; despite the continuation of some labor service commitments into October, the campaign was limited to no more than 120 and as little as 16 hours within a four-week span. After the 25 November 1945 elections had installed representative democratic governments at the Bund, Land, and Gemeinde levels, the occupation authorities-at least the Western Allies-felt that they could demand cooperation from democratically sanctioned officials to mediate between the Austrian population and the victorious powers in matters of post-conflict reconstruction. It was in this spirit that American Brigadier General T. E. Lewis, chief commander of the US Section of the Vienna InterAllied Command (VIAC) demanded of Mayor Korner that he "report the reason why adequate labor is not being employed and what means you have put into effect or contemplate putting into effect immediately in order to secure adequate labor."46 Korner's reply stressed a lack of available labor power due to the fact that between 150,000 and 200,000 Wiener "from the age groups most capable of work" remained in Allied POW camps. This meant that "women, old people, and youths" formed the largest part of the population capable of taking up short-term labor service. Korner concluded that ultimately "it does not lie within my power to interpose any kind of decree. The federal government alone-and in my opinion, only with support from the Allies, 
moreover-is capable of taking measures to remedy this situation:'47 1t was abundantly clear to Austrian officials and the Allied authorities that prisoners of war could not be repatriated rapidly enough to address pressing reconstruction needs. A rather substantial pool of labor did exist if one took into account the very people whom Korner had enlisted for the September Arbeitseinsatz-primarily former National Socialists on the one hand, and the unemployed, underemployed, or nonessentially employed on the other. In short, the pressing need for labor power remained fundamentally linked to the still-unresolved matter of denazification, the enlistment of Arbeitsscheue and black marketers, and the cultivation of self-sacrifice in the interest of an anticipated democratic civic culture.

Austrian government officials and particularly OVP and SPO representatives were hopeful that federal Arbeitspflicht legislation would play a vital role in stimulating the country's postwar recovery. Mandatory labor appeared all the more important, given the significant number of soldiers killed, injured, or held as POWs. Further, an internal dislocation of the labor force had occurred as people fled the Red Army for the perceived safety of western Austria, and the emergence of the black market during the initial postwar months presented a challenge to initial recovery. These factors placed a premium on effective recruitment and allocation of reconstruction labor. Yet the Arbeitspflichtgesetz ratified on 15 February 1946 should be understood as more than a matter of labor recruitment in and of itself; it also represented a component of an ongoing denazification process. Indeed, those targeted in the first instance were ex-Nazis, as defined in the draft Nationalsozialistengesetz that followed from the 1945 Verbotsgesetz. Those targeted by the draft law had been SS members, storm troopers, Nazi functionaries, or deco- rated NSDAP members, or had committed war crimes-even if they became party members after the Anschluss. (Such individuals had been designated "implicated" [belastet], as noted above.) In addition to losing their political rights until at least 30 April 1950-a period later reduced-those in the belastet category were barred from working in the civil service or holding certain professional positions as lawyers, accountants, or financial advisors, enjoying leading positions in public or private economic enterprises, teaching, serving in the police or security services, or working in the entertainment industry.48 The version of the Nationalsozialistengesetz ratified and approved by the Allies identified Belastete for compulsory labor service under the concurrently drafted Arbeitspflichtgesetz.49

Individuals designated "less implicated" (minderbelastet) found themselves subjected to substantial fines rather than imprisonment, deprived of political rights, and faced with the employment limitations suffered by Belastete until 30 April 1948.50 These were people who had become "ordinary" Nazi Party members or were awaiting confirmation of membership between Austria's absorption into Germany on 13 March 1938 and the end of the war, did not belong to any organizations deemed criminal, and had not committed crimes against humanity or public order. It is significant that Minderbelastete were not specifically targeted for compulsory work assignments, yet along with black marketers and labor shirkers they were not exempted from labor deployment and could be enlisted where local authorities deemed it necessary. Special commissions composed of representatives from all three antifascist parties reviewed the registration forms submitted by all former Nazis and assigned them "implicated" or "lessimplicated" status on the basis of the data provided. Such information required corroboration through personal references-whose trustworthiness could be subjected to 
further scrutiny- and in the last resort the relevant zonal occupation authority reserved the right to make any final determination concerning an individual's designation. Ultimately, some 440,000 former Nazis were designated minderbelastet. According to revisions in the Nationalsozialistengesetz introduced in February 1947, the above-mentioned prohibitions against their employment were relaxed significantly, although not done away with altogether.51

As noted, the draft Arbeitspflichtgesetz developed in February 1946, which enjoyed support from the OVP-SPO coalition, was linked closely to denazification legislation. In fact, Ehemalige were the primary group identified by the Arbeitspflichtgesetz. The second paragraph of $\S 1$ stipulated that men between the ages of sixteen and sixty and women between sixteen and fifty who had registered as Nazis according to the 8 May 1945 Verbotsgesetz were required to per- form labor service.52 This provision was more severe than the original compulsory labor clause in the Verbotsgesetz; the latter had called only for employment of those who would later be designated as belastetet in urgent work (so-called sofort Arbeit). This form of labor was intrinsically physical-that is, the removal of war-related rubble from streets, waterways, and bombed- out housing or production sites-and the strenuous nature of the work derived, in part, from punitive considerations. However, as SPO parliamentary deputy Wilhemine Moik observed, compulsory labor as envisioned in the new Arbeitspflichtgesetz did not stem from a desire for revenge or feelings of hatred toward ex-Nazis. Rather, she emphasized that it "is probably the mildest form of expiation:' 53 The Arbeitspflichtgesetz did not designate that their labor should be more onerous than those who were merely unemployed or engaged in "non-essential" labor. Individual firms or government bureaucracies entrusted with reconstruction projects would submit work-detail requests to the relevant Landesarbeitsamt,54 and individuals subject to labor service would be assigned to one the following project sectors, listed below in the prioritized rank order outlined in the legislation:
a) emergency work required by occupation authorities;
b) agricultural production and transport of foodstuffs, emergency repairs of enterprises connected to the foodstuffs industry and foodstuffs distribution network;
c) demolition of buildings beyond repair and in danger of collapse; manufacture of building materials and machine tools for reconstruction; emergency repairs on apartments and buildings designated as most pressing by communal authorities;
d) emergency repairs on sanitation facilities, sewer lines, and water pipes;
e) energy production (e.g., electricity, coal mining) and distribution;
f) emergency repairs on roadways, public transportation lines, and railroad tracks; g) emergency work to stem the danger of flooding. 55

Austrian politicians, particularly Social Democrats, stressed that Arbeitspflicht legislation would assume none of the draconian and dehumanizing features of National Socialist Zwangsarbeit.56 Rather, similar to the September 1945 Arbeitseinsatz in Vienna, former Nazis would enjoy the very same social protections under the law as anyone else employed in labor service. For example, a medical examination, conducted by doctors provided by the local Landesarbeitsamt, would determine if individuals were robust enough to fulfill their six-month compulsory labor service commitments.57 Social welfare considerations would not discriminate against those engaged in Arbeitspjlicht either, regardless of their previous political or employment status. For instance, health 
insurance would be provided to all laborers employed under the Arbeitspflichtgesetz; they would also be compensated at the same wage level as those working in these sectors without Arbeitspflicht, and a one-time round-trip travel allowance would assist those required to leave their home regions for their designated labor sites.58 Foreigners were exempt from compulsory labor, insofar as they did not have permanent residence in Austria (a particular benefit for DPs), and victims of National Socialism-a broad group including the politically, religiously, and "racially" persecuted-remained free from labor service assignments.

Although the Arbeitspflichtgesetz did not formally enter into effect until 25 July 1946 (BGBL Nr. 36), Austrian authorities began the recruitment and deployment of labor during the weeks preceding its introduction. Between 1 May and 31 July 1946 the Landesarbeitsümter reviewed 413,748 registration forms and earmarked a total of 3,198 individuals for compulsory labor assignment with private firms requesting assistance. The majority of these assignments occurred in Styria-a total of 1,798 or 56.2 percent of all of those reported; Tirol followed with 508 deployments (15.9 percent), and Carinthia with 415 (13 percent).59 No comparable comprehensive data elucidate the number of individuals employed directly by the public sector across Austria.

Vienna's Landesarbeitsamt did not report any requests for labor from private enterprises; Gemeinde authorities noted that Viennese firms doubted that those obliged to work would do so with sufficient enthusiasm and were therefore reluctant to accept labor deployment without the firms' representatives having a say in allocation. On the other hand, ample evidence suggests that municipally directed reconstruction projects did not hesitate to employ by hook or by crook individuals-Nazis or others-who fell under the terms of Arbeitspflicht legislation. Reports from the Wiener Polizeidirektion detail raids by police and occupation troops on coffee houses, clubs, and public gathering spots during daylight working hours that led to the detention of hundreds of black marketers and other questionable characters. Many of those taken into custody subsequently found themselves assigned to clean up war-damaged sections of the city. 60

Protests, entreaties, and stalling maneuvers from those who wished to avoid municipal labor service projects met with little sympathy from city authorities. Two very different examples help illustrate this point. Josef H., a former Social Democrat and Schutzbundler who fled Vienna for Brno after the February 1934 civil war, received notification that he was to resume working for the Bundesbahn in Vienna-but in a menial capacity, rather than in his earlier role as a locomotive conductor. His demotion resulted from his previous affiliation with the NSDAP. Herr H. had returned to Austria and joined the SA, dating his membership from 1937-which earned him Illegale status under the Verbotsgesetz-in order to end a seven-year spell of joblessness and secure a position with the Deutsche Reichsbahn in Vienna. He claimed never to have worn the SA uniform or sported the swastika as a lapel pin or armband. Forced to register as a Nazi in his home district of Wien-Brigittenau, Herr H. appealed to the Bürgermeister that he was being persecuted as a Nazi, although he insisted his sentiments had always remained firmly Social Democratic. Rather than take up labor service below his self-perceived professional and living standards, Herr H. made clear in his appeal that he was prepared to continue living from his savings and wait for his reinstatement if cancellation of his assigned labor service hours proved impossible.61 The tone of Herr H.'s letter registers bewilderment and despair, as well as an inability to comprehend how his opportunistic 
choice to seek NSDAP affiliation-and during the time of illegality, no less-could have landed him in difficulties. Without corroborating evidence, it is impossible to determine if he backdated his SA membership to 1937 in order to gain employment after the Anschluss-or, for that matter, if he had in fact held himself at a distance from the Nazi Party between 1938 and 1945. The director of the Bürgermeisteramt replied: "[I)nquiries revealed that you 'have lived from savings' since 8 August 1945 and have not undertaken to enter into any work whatsoever, although it has been offered to you many times over. As long as you are not willing to contribute actively to the reconstruction of Vienna and of Austria, you can hardly expect to find a promotion [to your earlier position with the railway]. You, a thirty-two-year-old man, should be a willing model of keen activity to our over- worked Bürgermeister, instead of burdening him with concerns that you could address through your own energy."62 Herr H.'s case offers an example of how reluctant municipal authorities were to indulge individuals who sought either to shirk their responsibility to make good their political errors, or who sought to secure shortcuts to better paying and less arduous work.

Measures taken against Hans M., the owner of a transport firm who rejected municipal directives to make a truck available for labor service, provide another perspective on shirkers. Herr M. not only refused to comply with the city's order, but according to witnesses he heaped abuses upon officials from Magistratsabteilung 47 (Transportlenkung) who had come to his garage for the vehicle. From the date of the initial order on 21 June 1946 until17 July 1946, Herr M. refused to release the truck. He was charged with insulting public officials and aggressive behavior and summoned to court and to the district administrative office in Wien-Ottakring.63 While the basis for Herr M.'s obstructionism and anger cannot be discerned from the documentation, one might speculate that he intended to use the vehicle for black market purposes that would have yielded more than the standard rate applicable under the Arbeitspflichtgesetz; otherwise there would have been little reason for his noncompliance. Involvement in black market activity could not be proved on the basis of available evidence, and the authorities limited charges against Herr M. to Amtsehrenbeleidigung and obstruction of the law.

Allocation of all available hands and every piece of working equipment to labor service became still more pressing as improved weather from spring through summer 1946 permitted intensified efforts. However, as the following example from August 1946 demonstrates, work did not always proceed as smoothly as good weather might have allowed. In Wien-Hietzing, groups of twenty and thirty-nine former Nazis turned out for their designated labor assignments on Saturday, 11 August, and Sunday, 12 August, respectively. On Saturday morning, only three cubic meters of debris were removed because the individual responsible for organizing the trucks and drivers clocked out at 12:30 with the explanation that Saturdays only counted as half-days; in addition, only two of the promised three trucks had materialized. Nonetheless, the Ehemaligen received their full daily wage from the Gemeinde, with the understanding that it had not been their responsibility that work could not continue. On Sunday morning, the larger contingent arrived at the staging point by 7:00, but none of the trucks or employees of the trucking firm appeared; at 9:30, the district official responsible for overseeing the Arbeitseinsatz concluded that he had no choice but to send the laborers home, this time without compensation.64 In response to a formal complaint from Wien-Hietzing Bezirksvorsteher 
Josef Cudlin (OVP), the Stadtbaudirektor replied that Magistratsabteilung 25, the department responsible for addressing war-related damage to municipal buildings, was regrettably not in the position to compel either firms providing drivers and trucks or the Allies, who frequently pledged to loan vehicles, to make good on their promisesparticularly in the frequent case of gasoline shortages.65 Similar incidents reported by district representatives and district branches of central municipal offices prompted the city manager, Magistratsdirektor Dr. Kritscha, to issue a directive to all district authorities and relevant city departments that Magistratsabteilung 25 could not function as a guarantor of transportation. Officials in the districts would remain responsible for arranging and verifying arrangements with firms or occupation authorities providing drivers or vehicles.66 Coordination of labor, vehicles, fuel, and food for workers determined the success of Arbeitseinsütze throughout the city, and the proper balance could never be assured.

Vienna's director of urban planning and reconstruction estimated that, as of April 1946 , almost 700,000 of what had originally been nearly 800,000 cubic meters of debris still cluttered streets and public squares and that another 2.5 million lay in bombed-out houses, factories, warehouses, and public buildings.67 Falling material from damaged buildings remained a constant danger, capable of injuring or killing pedestrians and blocking traffic. 68 Detailed weekly reports made it plain that two factors were vital for an effective campaign to remove the detritus of war from Vienna's urban space: a consistent supply of sufficiently motivated workers and the availability of trucks or horse-drawn wagons capable of traveling on streetcar lines to assist in rubble clearance.69 Difficulties in transportation-alleviated considerably when British, American, and French forces began to supply trucks, bulldozers, and backhoes in larger numbers as of spring 1946-trying working conditions, the absence of facilities to provide workers with on-site meals, and highly demanding physical tasks coupled with low caloric intake also acted as impediments to uniform and consistently successful implementation of Arbeitspflicht, both before and after the formal introduction of the law.

According to figures issued by the Austrian government, the Arbeitsümter recorded a far greater demand for workers (again, initially weighted toward the western Lander and Styria) than the available labor pool proved able to sustain.70 This placed a greater premium on employing former National Socialists in rubble clearance, as well as in snow removal during the bitter winter of 1946/47, as had been the case in 1945/46.71 In certain cases Ehemalige chose suicide as an alternative to losing their professional status or the shame of what they considered forced labor.72 While this choice was far from the norm, it conveys a sense of the marginalization perceived by those held to be unrepentant Nazis and effectively confirmed the suspicions of those who doubted that they could ever be redeemed. More frequently, as illustrated by the representative examples provided above, Ehemalige and others obliged to work issued pleas or offered excuses in their efforts to escape labor service.

\section{Assessing the Efficacy of Arbeitspflicht in the Broader Austrian Context}

Arguably, Arbeitspflicht was more effective in the public sector than in the private; we have already noted that municipal, provincial, and federal agencies were less concerned about the work ethic of those subject to labor service than were private firms. 
In the public sector, wages could be kept manageably low because the largely unskilled labor of rubble removal and clean-up did not require high rates of compensation. Yet historian Dieter Stiefel underscores the strains created by the "artificial unemployment" that resulted in no small measure from the prevention of almost 500,000 former Nazis, many of them professionals, from employment in their fields of specialization during the first two years of the Second Republic. When modifications to denazification legislation permitted most Ehemalige to return to work in 1947, Stiefel observes, "reconstructioni.e., the re-establishment of the socio-economic basis of a modern industrial society ... one of the fundamental conditions for the reestablishment of the Republic of Austriastood in a conflict of interest vis-a-vis political purification."73 It would appear that the latter was sacrificed to the exigencies of the former.

On balance, then, how can we evaluate the success of Arbeitspflicht throughout Austria and particularly in Vienna? From a Social Democratic perspective, although the employment of former National Socialists was formally consistent with "re-education through expiation" rather than blanket punishment, 74 the broader, ostensibly civic educational element of Arbeitspflicht was never manifest in the letter of the law or in its application.75 On the whole, the Austrian population greeted compulsory labor service unenthusiastically. The Landesarbeitsamt in Tirol reported that, in some districts, police consistently had to round up those who attempted to evade their work responsibilities.76 According to reports from Vorarlberg, Upper Austria, Lower Austria, and Styria, similar difficulties prevented the smooth implementation of the law, and those who did show up for labor service rarely displayed particular enthusiasm for their assignments.77 To ensure that the population was gainfully employed, the federal government required citizens to display their labor certification IDs in order to acquire food ration cards-a practice already employed in Vienna in the summer and autumn of 1945. Those obliged to fulfill labor service received their official cards if they registered at the Meldestelle and appeared at their designated labor sites. However, industrious individuals responded with a new industry in counterfeit records designed to verify full-time employment status, and black market foodstuffs remained available for those willing to pay or trade.78 Moreover, the punitive effect that legislators intended the law to have on Ehemalige seemed lost in practice, at least in the less war-damaged western and southern provinces, where demand for unskilled physical labor proved less overwhelming (with a few notable exceptions, such as in parts of the industrial city of Linz). In these areas, fewer Ehemalige found themselves pressed into what would have been humiliating manual labor-a consideration worth taking into account, since many Nazis had benefited from better job placement during the 111 ird Reich and tended to dominate the middle to higher salary levels associated with the free professions, engineering, and management. This made them more expensive for private firms that might have required their services; the public sector in these parts of Austria, which would have been able to pay them the standard rate for unskilled heavy labor, had less of a need for them.79 Vienna remained an exception, where the public sector absorbed the lion's share of those subject to Arbeitspflüht- the majority of them former National Socialists-for rubble removal and seasonal work such as snow clearance.

Despite the law's widespread lack of popularity, Landesarbeitsümter reports of noncompliance, continued objections from the Federal Chamber of Labor (Arbeiterkammer), increasingly tepid support from much of the SPO parliamentary 
faction, and outright KPO opposition, the Austrian parliament voted an extension of compulsory labor service for the calendar year 1947 and again for 1948.80 While one of the alleged purposes of extending the provisions of the law was to compel more systematically former National Socialists to work for the benefit of the fledgling republic, the text of the law was revised to correspond to categories of culpability delineated in the 1947 denazification law.81 Thus, Minderbelastete were no longer singled out for harsher treatment than those recruited citizens who had not gone over to the Nazis, and the only special provision for the Belasteten was the preservation of the upper age limits for those liable to fulfill labor service.82 When the Amnestiegesetz of 21 April 1948 removed the legal restrictions against 487,067 Minderbelastete, reeducation through "labor-penance" became even less meaningful. 83

Nonetheless, the decision not to renew the Arbeitspflichtgesetz at the end of 1948 ultimately had rather little to do with the law's reception among the population, the shortcomings identified by the provincial labor authorities, or the judgment that Ehemalige and work-shirkers had been rehabilitated. Once the Amnestiegesetz entered into effect, the OVP and SPO entered into competition for former Minderbelastete, now qualified to vote in the 1949 elections. Additionally, a massive influx of foreign assistance and increased engagement on the part of Austrian citizens eclipsed Arbeitspflicht as an engine in the areas of agricultural labor and rubble removal or construction projects in towns and cities. While United Nations relief aid had helped to alleviate much of the country's short-term need for foodstuffs between April1946 and June 1947,84 the majority of debris had been removed by 1948, utilities had been restored, and with the introduction of wide-ranging longer-term assistance provided by the Marshall Plan-including machinery to expedite the final stages of clean-up and early reconstruction activity initially completed with human hands-rebuilding could proceed at a more rapid pace. 85

Calculated in raw dollar totals, direct aid through the Marshall Plan reached approximately $\$ 417.4$ million between 1948 and 1950 and another $\$ 232.4$ million in credits between 1948 and 1951.86 Further increases in foodstuff delivery, fertilizers, vehicles, fuel for transportation and production, and material to repair or build rail lines and roads represented essential elements for initial economic recovery. In the end, increased rationalization and mechanization of Austria's transport, agricultural, and industrial sectors eliminated the need for sizable emergency labor resources designated to each of these areas. This massive infusion of foreign, largely Marshall Plan, aid that began to prime the pump for economic reconstruction during the late1940s and early 1950 s, together with the majority of the Austrian population's willingness to work to achieve material comfort, became key contributing factors for Austria's reconstruction and eventual recovery.

Both Social Democratic and Catholic-conservative political leaders were united in their conviction that economic prosperity represented the surest defense against resurgent extremism on the part of those who had supported far-left or far-right political parties. When considered in this light, integration of all but the most seriously implicated Austrian Nazis appeared decisive if Austrian society was to achieve, and sustain, material comfort and social peace. 87 Steadfast OVP and SPO anticommunism facilitated smooth Austrian entry into the European Recovery Program (ERP) recipient network, where economic aid served the twin goals of creating social and political stability. 88 However, 
most ERP counterpart funds were not directed to Vienna, and in the capital this served as something of a brake on initial reconstruction and recovery in comparative terms. Historian Günter Bischof notes that "[t]he westward movement of lead sectors in the Austrian economy (especially war-related heavy industry) already started during the war and accelerated after the war-... would come to characterize the postwar Austrian economy. Next to Nazi investments in western Austria, Marshall funds were the crucial engine for Westverschiebung. Fully 81 percent of the ERP funds were invested in the Western zones, only 19 percent in the Soviet zone and Vienna." 89

Not surprisingly, by the early 1950s the Western Allies began to take on the role of agents for recovery and guarantors against Red Army expansion outside of the Soviet zone of control. Concurrently, Austrians saw ERP assistance as central to recovery and regarded physical reconstruction, economic growth, and the maintenance of social peace as the surest ways to buttress the young Second Republic. The beneficial effects of hard work, access to adequate supplies of consumer goods, the promise of a secure social welfare net, and good standing in the international community represented for them a more palatable means for transforming Austria than did denazification measures and compulsory labor service. Indeed, for many Austrians who identified with the designation "first victims of Nazi aggression" in the Allies' Moscow Declaration (1943), occupation, denazification, and labor service raised irreconcilable tensions inherent to the Austrian victim/perpetrator dyad.

\section{Evaluating Arbeitspflicht in Vienna as a Component of Reconstruction}

While the social, economic, and geopolitical considerations discussed above clearly influenced perceptions of Arbeitspflicht among politicians, administrators, and ordinary Austrians, there can be little doubt that labor service facilitated initial reconstruction efforts. This was particularly true in Vienna, where the greatest concentration of warrelated destruction had been inflicted.90 Although legally mandated labor service remained in effect until the end of 1948, evidence compiled by municipal authorities suggests that considerable progress occurred between September 1945 and July 1946-that is, prior to the introduction of federal labor service legislation. Indeed, the progress made under the auspices of Korner's decree during the nine months prior to the introduction of the Arbeitspflichtgesetz cannot be underestimated. For example, from late August to late December 1945, a total of 157,908 of a calculated 794,973 cubic meters of rubble that had cluttered Vienna's streets, squares, and other surfaces had been hauled away by hand and by human- or horse-drawn wagons. At this point, Austrian-owned or Allied vehicles were only rarely available for assistance.91

Broad assessment of municipally directed Arbeitseinsatze can be made on the basis of status reports surviving from the better part of 1946 that describe efforts both before and after the for- mal introduction of the Arbeitspflichtgesetz. From early April to mid November 1946, weekly reports prepared by the Stadtbauamt for the Bürgermeister and his Magistratsdirektor listed the number of workers employed and the amount of debris removed in cubic meters, as well as the number of railroad cars, streetcars, trucks, and backhoes available. Over the thirty-one weeks for which complete data exist, some 26,539 labor deployments are registered-an aggregate figure that does not take into account the number of assignments per worker during a given week, or the number of 
weeks that the average person engaged in labor service. A daily average of 856 people entered into working relationships, but during certain periods-early in the sequence of weekly reports and prior to the formal introduction of the Arbeitspflichtgesetz in July-as few as 272 laborers appeared for work during the week ending on 10 April, as opposed to a high mark of 1,180 for the week ending on 15 September.92 Between 1 January and 14 November 1946, these laborers removed an additional 556,899 cubic meters of debris that littered the city.93 Unfortunately, available archival sources do not offer a systematic representation of the precise subcategories of those obliged to work-that is, Ehemalige, prisoners (black marketers, thieves, etc.), shirkers, and "untainted" individuals diverted from other sectors. Rather, one must remain satisfied with the insights gained into the composition of the labor force engaged in municipal projects at given moments during 1946, 1947, and 1948. For example, in the first half of August 1946, of the 1,032 individuals engaged in debris removal, 555 counted as Gemeinde- employed laborers (stündige Arbeiter), 159 as convicts (Strafgefangene), and 318 as National Socialists.94 This still represented a rather high proportion of Ehemalige to city workers. The total declined into 1947, and ex-Nazis became only marginally significant as part of the city's reconstruction labor force from late 1947 through the end of 1948.

Several factors seem to have accounted for this trend. By late 1946, the Magistratsdirektion reported that intensive repairs to the city's gas and water lines, electricity network, and sewage system had achieved a 95 percent restoration of their prewar integrity,95 a task that required the skill of engineers and specialized laborersincluding ex-Nazis. Such labor required a delicate balance between rubble removal and repair. City engineers proceeded from the assumption that the heavy work of debris clearance from street surfaces could not proceed in earnest until subterranean utility lines had been repaired and resealed. Once such tasks had been accomplished and access to these areas cleared for heavy vehicles and machinery, the grueling physical labor of wholesale rubble removal and the hunt for reusable construction materials (bricks, beams, steel rods, roofing tiles, etc.) could proceed in earnest.96 As 1946 drew to a close, only 80,166 cubic meters of rubble, or less than 10 percent of the Stadtbauamt's original calculation for war-induced destruction, remained to be cleared. Thus, aside from directing workers to seasonal tasks such as street and sidewalk snow removal or assistance with the autumn harvest on the periphery of the city, municipal authorities had largely addressed the most pressing tasks to which they could direct former Nazis during the calendar years 1947 and 1948.

When the Arbeitspflichtgesetz lapsed in December 1948, the Kontrollamt der Stadt Wien concluded that, in Vienna's then twenty-six districts, 125,604 former Nazis had registered for labor service during the thirty months the law had been in effect. A total of 14,022 were assigned to labor-an average of approximately 467 individuals per month.97 Monthly averages would understandably have been larger during the period from the law's introduction in July 1946 through early 1947, during which time the final sustained push for debris clearance and fundamental repair of infrastructure-and another winter's worth of intensive snow removal-took place. Average labor allocations would have been far lower in the last months of Arbeitspjlicht, when the demand for cost-effective municipal labor power eased markedly and competition for the support of reenfranchised Minderbelasteten in the coming 1949 elections increased considerably. Moreover, the majority of Austrian POWs had returned home from Soviet camps; virtually all had been 
repatriated from Western Allied detention by late 1948, although some would remain in custody until as late as 1955. These men represented an additional source of labor power for reconstruction projects in Vienna and throughout the country.

Despite expressions of dissatisfaction by individual former National Socialists, their inclusion in mandatory labor service, particularly during Vienna's first two years of postwar reconstruction, proved important-arguably more so in the capital than elsewhere in Austria. To what extent did labor service represent a punitive and possibly expiatory act-or was it first and foremost the application of raw human energy to difficult tasks without a decidedly punitive element? During the months prior to the introduction of Arbeitspjlicht- particularly from early summer through early autumn 1945-antifascists at the Bezirk level pressed Nazis into often haphazardly organized labor gangs oriented at least as much toward punishment as toward coordinated and purposeful work. Despite the confusion prevalent during these initial months of provisional government, antifascists rather effectively targeted Nazis both "large" and "small;' ranging from notorious figures who had not fled to petty tyrants and bullies. Faced with wild Soviet requisitioning of Viennese labor, compelling Ehemalige to fulfill the Red Army's needs and to begin immediate post-conflict clean-up appeared desirable and justified. If Ehemalige had profited from the Nazi regime, they could be held responsible for the consequences of their support with very few pangs of conscience; antifascists who assumed administrative and executive posts at the Bezirk or Gemeinde level could take grim satisfaction that their former oppressors, stripped of the trappings of power and privilege, now labored under difficult physical conditions and fear of arrest by the Soviet authorities. Pedagogic considerations did not appear to enter into serious consideration initially. Proponents of "making an example" of former Nazis might have pointed out that the population could see how the mighty had fallen, and that Ehemalige could reflect upon the justice to which they had been subjected; however, there is no compelling evidence in the archival record or frequent indication in the popular press to indicate that this consistently proved to be the case.

By the time mayoral edicts and, in turn, federal legislation regulated the terms and conditions of labor service, focus had shifted decidedly from retribution to reconstruction. Ultimately, Arbeitspflicht for former Nazis-and for those in other categories affected by the law-could never be represented unequivocally to the Viennese population as a form of restitution to society at large. Indeed, since Austrian authorities forbade any special badges, markers, or other designations for former Nazis or others engaged in Arbeitspjlicht, it would have been difficult for ordinary Viennese to determine whose labor was expiatory, unless known Ehemalige worked in their own neighborhoods. The representative case studies I have employed suggest, moreover, that Ehemalige were far from universally enthusiastic about either the restorative potential that their labor would have for their own integrity or the notion that their work served as an opportunity to earn integration into a new Austrian society. Appeals issued to the Bürgermeisteramt from Nazis or others subject to Arbeitspjlicht indicate that most sought special dispensations based on health concerns or references to a previous Social Democratic affiliation. The fairly rapid evolution of Austrian denazification legislation, the foundational myth of Austria as first victim, and the extension of the vote to the Minderbelasteten in 1949 also circumscribed the extent to which Arbeitspjlicht served as a meaningful exercise in civic education for those affected and for observers in a restored 
Red Vienna. In the end, managing labor resources promoted initial reconstruction, but Vergangenheitsbewültigung was sacrificed to political expediency with the April 1948 amnesty law and the restoration of political rights for Minderbelastete in 1949-a legacy that persisted stubbornly into the late twentieth century.

\section{Notes}

1See, for example, Jeffry M. Diefendorf, ed., Rebuilding Europe's Bombed Cities (New York, 1990); as well as Werner Durth and Niels Gul chow, Tri:iume in Trummem. Stadtplanung 1940-1950 (Munich, 1993). Unless otherwise noted, all translations in this article are the author's.

2 The literature is quite vast, and the following are only a modest cross-section of relevant works. Sec, for example, Josef Foschepoth, "German Reaction to Defeat and Occupation," and Frank Stern, "1he Historic Triangle: Occupiers, Germans, and Jews in Postwar Germany; both in West Germany und er Construction: Politics, Society, and Culture in the Adenauer Era, ed. Robert G. Moeller (Ann Arbor, 1997), 73-92 and 199-230, respectively; Norbert Frei, Vergangenheitspolitik. Die Anfi:inge der Bundesrepublik und die NS-Vergangenheit (Munich, 1999); Jeffrey Herf, Divided Memory: The Nazi Past in the Two Germanys (Cambridge, MA, 1997); Peter Reichel, Politik mit der Erinnerung. Vergangenheitsbewi:iltigung in Deutschland. Die Auseinandersetzung mit der NS-Diktatur von 1945 bis heute (Munich,2001); Klaus Neumann, Shifting Memories: The Nazi Past in the New Germany (Ann Arbor, 2000); Bill Niven, Facing the Past: United Germany and the Legacy of the Third Reich (London, 2002).

3 0n denazification, see the now-standard works of Dieter Stiefel, Entnazijizierung in Osterreich (Vienna, 1981); and Sebastian Meiss!, Klaus-Dieter Mulley, and Oliver Rathkolb, eds., Verdri:ingte Schuld, verfehlte Sühne: Entnazifizicrung in Osterreich (Bad Vüslau, 1986); as well as works published by the Dokumentationsarchiv des üsterreichischen Widerstandes, such as Winfried R. Garscha and Claudia Kuretsidis-Haider, Die Verfahren vor dem Volksgericht Wien (1945-1955) als Geschichtsquelle (Vienna, 1993). On Vergangenheitsbewültigung in Austria, see, among others, Heinz P. Wassermann, "Zuviel Vergangenheit tut nicht gut!" Nationalsozialismus im Spiegel der Tagespresse der Zweiten Repub- lik (Innsbruck, 2000); Meinrad Ziegler and Waltraud Kannonier-Finster, Osterreichisches Gedüchtnis. Ober Erinnern und Vergessen der NS Vergangenheit, 2nd ed. (Vienna, 1997); Anton Pelinka and Erika Weinzierl, eds., Das grosse Tabu. Osterreichs Umgang mit seiner Vergangenheit, 2nd ed. (Vienna, 1997); Robert G. Knight, "Absentee Germans-The Second Austrian Republic and the Nazi Past;' TelAviver Jahrbuch fur deutsche Geschichte 26 (1997): 197-214; Berthold Unfried, "Versionen der Erinnerung an Nationalsozialismus und Krieg in Osterreich und ihre Veranderungen in der Waldheim-Debatte;' Zeitgeschichte 9/10 (1997): 302-16; Richard Mitten, The Politics of Antisemitic Prejudice: The Waldheim Phenomenon in Austria (Boulder, 1992); Rudolf G. Ardelt, "Zumutungen und Auseinandersetzungen. Reflexionen zur Ausstellung 'Vernichtungskrieg. Verbrechen der Wehhnacht 1941-1944' in Linz," Zeitgeschichte 11/12 (1997): 346-64; Gerhard Botz and Gerald Sprengnagel, eds., Kontroversen um Osterreichs Zeitgeschichte. Verdrüngte Vergangenheit, Osterreich Identiüit, Waldheim und die Historiker (Frankfurt am Main, 1994).

4 See Ela Hornung and Margit Sturm, "Stadtleben. Alltag in Wien 1945 bis 1955;' in Osterreich 1945-1995. Gesellschaft-Politik-Kultur, ed. Reinhard Sieder, Heinz Steiner, and Emmerich Talos (Vienna, 1995), 54-67; on Vienna, see also Hannes Swoboda, ed., Wien. Identitüt und Stadtgestalt (Vienna, 1990); and Siegfried Matti, "Vienna since World War II:' in Composing Urban History and the Constitution of Civic Identities, ed. John J. Czaplicka and Blair A. Ruble (Washington, DC, 2003). For examples of a broader, non- Viennese focus, see Archiv der Stadt Linz, ed., Entnazifizierung und Wiederaufbau in Linz, Schriftenreihe Historisches Jahrbuch der Stadt Linz, 2nd ed. (Linz, 1996); and Erich Marx, ed., Befreit und Besetzt. Stadt Salzburg 1945-1955, Schriftenreihe des Archivs der Stadt Salzburg, 7 (Salzburg, 1996). 5 See the table in Stiefel, Entnazifizierung, 93.

6 Hans-Georg Heinrich, "Wien: Politische Kultur im Umbruch: Patronagesystem und politische

Identitat;' in Wien. Identitüt und Stadtgesta/t, ed. Swoboda, 133.

7Ibid., 134.

8 Mattl, "Vienna since World War II;' 251.

9 Magistrat der Bundeshauptstadt Wien, ed., Verwaltungsbericht vom 1. April 1945 bis 31.

Dezember 1947 (Vienna, 1949), 218.

10 lbid., 330. 
11Ibid., 218.

12 Magistrat der Bundeshauptstadt Wien, ed., Verwaltungsbericht vom 1. Janner 1948 bis 31. Dezember 1949 (Vienna,1951), 270.

13 Ibid., 279.

14 Wiener Stadt- und Landesarchiv (hereafter cited as WrStLA)-MD A6 Box 1, BA 137/45, "Korner an den Herro Bezirksvorsteher fur den ... Bezirk," 7 May 1945. Korner informed Lieutenant General Blagadatov, commandant of Soviet forces in Vienna, of his plan; Blagadatov acknowledged the wisdom of this directive and explained that he could ensure that Red Army troops stationed in Vienna accepted this arrangement, but that he was not directly responsible for the behavior of troops merely passing through the city. WrStLA-MD A6 Box 1 BA 127/45, "Der prov. Bürgermeister der Stadt Wien [Korner] an den Staatssekretar für soziale Verwaltung Herrn Johann Bohm;' 12 May 1945.

15 WrStLA-MD A6 Box 1, BA 127/45.

16 See, for example, WrStLA-MD A6 Box 2, BA 553/45, "Stadtrat fur Verwaltungsgruppe VErnahrungswesen, Magistrat der Stadt Wien;' 27 May 1945. This official left his apartment in Vienna's second district at 5:40 on 26 May to find a Red Army truck parked in front of the building. He was ordered to climb in by the sergeant in charge of the unit, despite the fact that he had a civil servant identification card issued by the Soviet commandant for Vienna. His papers were confiscated and he found himself driven to the third district with some twenty other men enlisted by the troops-among them a seventy-twoyear-old whose right hand had been permanently disabled during World War I, a man in slippers and a bathrobe who had left his apartment house to fetch water, and a grocery salesman. When the truck arrived at its destination in the eleventh district, the civil servant prevailed upon the sergeant that a member of the municipal administration had more important things to do than load and unload material, at which point his papers were returned to him and he had to make the long walk from Simmering to the Rathaus on foot, arriving late for work. "It is my opinion;' he concluded, "that countless workers employed in vital sectors are rounded up on the way to work like helpless animals. Through such incidents we incur great shortages in work of central importance and, moreover, this behavior does not contribute to an improvement in relations between the Red Army and the Viennese population: '

17 See Walter Praeger, ed., Das Nationalsozialistengesetz mit Verbotsgesetz (Vienna, 1946). 18 Praeger, ed., Das Nationalsozialistengesetz, Artikel Ill §10 (1), 29.

19 WrStLA-MD A6 Box 2, BA 616/45, "Hanner, Staatsamt für Inneres [Z1. 14.267-2/45, Vorgehen gegen Nationalsozialisten] an den Herro Bürgermeister in Wien, den Herro Polizeiprasidenten in Wien, die Landeshauptmannschaft für Niederosterreich in Wien, die Landeshauptmannschaft fur Steiermark in Graz. 9 June 1945.

20 Ibid.

21 WrStLA-M.Abt.218 A1 Box 62, IV/4 216/1945, "Betr. Arbeitsverhaltnis von zum Arbeitseinsatz herangezogenen Nationalsozialisten;' 6 July 1945. The document represented a response from the Staatsamt für Soziale Verwaltung to an inquiry by the Viennese Stadtbauamtsdirektion concerning ex-Nazis engaged in clearing rubble.

22 WrStLA-MD A6 Box 2, BA 934/45, "Staatsamt für Soziale Verwaltung an den Herrn

Bürgermeister der Stadt Wien General Korner, betr. Zuweisung von Arbeitskraften zu vordringlichen Arbeit in Wien;' July 1945 (no precise date).

23 WrStLA-MAbt.218 A1 Box 62, 18-204/45, "Mitteilungen der Magistratsdirektion: Meldung der Nationalsozialisten beim Arbeitsamt," 12 June 1945. The director of Vienna's Landesarbeitsamt advised Korner that "on the basis of the great lack of labor power, a complete exclusion of [Nazi] party comrades from economic life is not supportable." WrStLA-MD A6 Box 2, 934/45, "Landcsarbeitsamt Wien and den prov. Bürgermeister der Stadt Wien, Betr.: Arbeitseinsatz der Nationalsozialisten; 24 June 1945.

24 Korner explained to Honner that "complete removal of all party members and aspirants from public service would, in my opinion, bring with it an untenable burden to public resources:' WrStLA-MD A6 Box 2, BA 722/45, 30 June 1945. The occasion for Korner's note was Honner's directive from 9 June 1945 (Z1. 14267-2/45) that no special consideration was to be shown to simple NSDAP members or aspirants, as well as an 18 June 1945 complaint from socialist and communist organizations in the Floridsdorf-Kagran district that fascist elements still remained in the Bezirk administration.

25 "Arbeit und Essen:- Neues Osterreich, 12 July 1945.

26 "Der Schlurf," Neues Osterreich, 1 August 1945. Interestingly, the editorial's description of Schlurfs reflected some of the Nazi characterizations of swing kids: lazy (arbeitsscheu), long-haired, looselimbed, asocial types infatuated with the newest jazz recordings and entirely uninterested in contributing to 
the common good.

27 For an example of this poster, see WrStLA-MD A1 Box 628, MD 809/45. The text was reproduced as "Kundmachung-Magistrat der Stadt Wien. Aufruf," in Amtsblatt der Stadt Wien 50, no. 3 (12 September 1945): 6-7.

28 Ibid., 7.

29 See WrStLA-MD A1 809/45, "Hausliste für den Arbeitseinsatz im September 1945;' for an example of this form. At the time I submitted this manuscript for publication, the Bestand "Landesarbeitsamt" in the Wiener Stadt- und Landesarchiv had not yet been ordered and catalogued for researchers. Thus, it is not yet possible to ascertain how thoroughly these Hauslisten were completed on a house-by-house, street-by-street, and district-by-district basis- assuming, of course, that the archival record includes enough of these lists to draw meaningful conclusions. The form required that officials provide the street name, house number, and door number, the name of each adult resident, year of birth, sex, occupation, and number of hours worked per week; where the resident was employed, if the individual had been a Nazi Party member under $\S 4$ or $\$ 12$ of the Verbotsgesetz; if grounds existed to exempt the individual from Arbeitseinsatz; and space for the individual to confirm the veracity of the information with a signature. Officials at the Landesarbeitsamt then placed the individual in one of the four categories that determined the number of labor hours required, the time at which they were to appear for work, and the sector of the city where they would report each day for deployment.

30 WrStLA-MD A6 Box 4, BA 1873/45, "Der Leiter des Polizeikoat II. an den Herrn Bürgermeister der Stadt Wien General Korner;' 8 September 1945. This should have come as no surprise. In connection with the June-July edict issued by Honner and initiated by Korner, the Social Democratic Stadtrat Josef Afritsch had remarked to police officials that there were too few Nazis to rely upon for the scale of the task at hand. Although employing Nazis as a form of punishment or civic restitution was not unimportant in Afritsch's eyes, he considered it a mistake to limit such labor to Nazis alone ("die Nazifrage ist nur eine Detailfrage"). Afritsch maintained that the mobilization of all available Viennese assumed a greater urgency, given that severe transportation shortages would hamper clean-up ("das Entscheidenste ist die Transportmittelnot") and more labor power would be required. MD 378/45 betr. Arbeitseinsatz der Nationalsozialisten, "Allenvermerk über die am 11. Juli 1945 ... irn kleinen Sitzungssaale des Staatsamtes fur Inneres, General-Direktion für die otfentliche Sicherheit ... stattgefundenen Amtsbesprechung;' in WrStLA-MD A6 Box 2, BA 934/45.

31 According to reports by an American State Department observer, the average Viennese could not spend more than ten marks monthly on foodstuffs, given existing stocks and ration card allowances-forcing approximately half of the popula- tion to supplement its meager diet through black market trade at some time or other. "Memorandum by Martin F. Herz to Senior Military Officer, Political Division USACA, Vienna, September 14, 1945;' in Understanding Austria: The Political Reports and Analyses of Martin F. Herz, Political Officer of the US Legation in Vienna 1945-1948, ed. Reinhold Wagnleitner (Salzburg, 1984), 47. On the nutritional situation during summer 1945, see WrStLA-MD A1 Box 626, MD 361/45, "Mag- istral der Stadt Wien, Magistratsabteilung V/1, Verw.Gr.V-214/45 'Ernahungslage Wiens' an den Herro Stadtrat der Verwaltungsgruppe II, der Verwaltungsgrupe VI, der Verwaltungsgruppe IX, den Herro Magistratsdirektor:' 12 June 1945.

32 WrStLA-MD A1 Box 626, MD 361/45, "Ernahrungslage Wiens:' 12 June 1945. See also "Memorandum of 2 August 1945 regarding 'Notes on Food Situation in Austria:" in Understanding Austria, ed. Wagnleitner, 23f.

33 See, for example, Korner's report to Provisional Interior Secretary Hanner from 30 June 1945: "With respect to your decree of9 June ..., according to which there is no room for milder treatment of simple NSDAP members or party aspirants, I forward you the demands of two Viennese districts calling for the removal of all Parteigenossen and Parteianwïirter from public service.... A complete removal of all Parteigenossen and Parteianwi:irter from public service would, in my opinion, bring with it a tremendous burden on public administration that would prove untenable:' Korner urged that proper legal measures be taken to regulate those Ehemalige who should be dismissed and those who might continue to work. The demands issued stemmed from joint SPO and KPO resolutions drafted in the districts of FloridsdorfKagran and Wahring. WrStLA-MD A6 Box 2, BA 722/45. Expressions of dissatisfaction came from throughout the city. See, for example, WrStLA-MD A1 Box 627. MD 682/45, "Magistratisches Bezirksamt fur den 14. Bezirk an die Magistratsdirektion der Stadt Wien:-concerning 9 August demonstrations by socialist and communist workers and former concentration camp inmates against the continued employment of former Nazis in Wien-Penzing. According to $\S 10$ and $\S 12$ of the Verbotsgesetz, illegal ex- 
Nazis and those otherwise belastet (as identified in $\S 4$ and $\S 10$ ) were to be dismissed from the civil service. However, Dr. Kritscha, director of the municipal council (Magistratsdirektor), noted that "in very rare cases, if removal [of these indi- viduals] results in the shortage of qualified personnel who cannot easily be replaced and jeopardizes sustained municipal operations, a proposal for the continued employment [of these individuals] can be submitted to ... the Magistratsdirektion:' WrStLA-MD A1 Box 626, MD 300/45, 11 Tuly 1945 . The confusion within the city administration, among the general population, and with the four occupation powers required clarification. A group within the city administration led by Vizebürgermeister Paul Speiser (SPO) drafted guidelines consistent with the Verbotsgesetz for municipal and occupation officials alike. megale and Belastete were to be dismissed from public service, and nonillegal Nazis could retain their jobs at the discretion of their supervisors. WrStLA-MD A6 Box 4, BA 2262/45, 25 September 1945.

34 See the striking example of sixty-year-old Hans Ehrenreich, who in response to Korner's call for September Not- standsarbeitseinsatz eagerly volunteered his services in the interest of showing thanks and respect to "our beloved, now so heavily war-damaged Vienna:' Korner responded with heartfelt thanks, announced that he had given Ehrenreich's letter to the Rathaus-Korrespondenz for publication (perhaps with the hope that it would inspire-or shame-others to volunteerism), and advised him to inform his Hausvertrauensmann or Bezirksvorsteher that he was prepared to take part in the communal labor. WrStLA-MD A6 Box 4, BA 1800/45.

35 WrStLA-MD A6 Box 4, BA 2141/45.

36 WrStLA-MD A1 Box 629, MD1178/45.

37 WrStLA-MD A1 Box 631, MD 1858/45.

38 WrStLA-MD A6Box4,BA2139/45.

39 Ibid. Emphasis in the original.

40 Ibid.

41 No information on Frau $S: S$ visit to the Magistratsdirektion is included in the file. As a contrast, consider the case ofJose-

fine M., who appealed to Franz Popp in the SP6 Zel 1tralsekretariat on behalf of her husband, Robert. Herr M. had become a Nazi in 1931 and remained so until the NSDAP was outlawed in June 1933. Although he rejoined the party "for purely professional reasons" shortly after the Anschluss, Frau M. maintained that "in his heart he never was a Nazi and became more and more opposed to the methods of the NSDAP, never exercised any political function during the entire regime, and continually refused to do even the smallest tasks for the party, despite continual demands. He never wore the party symbol" Frau M. requested that her husband be released from labor service in Wien-Neubau, where the heavy labor he had been doing had exacerbated hisalreadyfragilestateofhealth,"whichanydoctorcanconfirm"Withoutsupportingevidencefrom public health officials, such requests oouJd not be granted. Verein fur die Geschichte der

Arbeiterbewegung-Politisches Arch..iv der SP6 (hereafter cited as VGA-PAdSP6), Zentralsekretariat, Allgemeine Korrespondenzen 1945, "M."

42WrStLA-MD A6 Box 5, BA 2733/45, Letter of7 December 1945.

43WrStLA-MD A6 Box 5, BA 2733/45, "MD Amtsvermerk vom 20.XIJ.1945:'

44WrStLA-MD AI Box 644, MD 2347/46, "Magistratsdirektion an den Herrn Leiter der

Einsatzstelle für ehemalige Nationalsozialisten im 21. Bezirk;' 20 August I946. 45WrStLA-MD AI Box 629, MD 1308/45.

46WrStLA-MD A1 Box 633, MD 225/46, "To: General 1heodor Koerner, Burgomaster City of

Vienna; Subject: Labor Shortage:' 18 January 1946.

47Ibid., "Korner an das Wiener Interallierte Kommando, US-Section, zu Handen Herro

Brigadegeneral T. E. Lewis," 31 January 1946.

48TheserestrictionsaredelineatedinPraeger,ed.,DasNationalsozialistengesetz, Artike!I§18a)- p),38-41. 49"Auf sie finden die besonderen Bestimmungen der Gesetze über Wohnungsanforderung,

Wirtschaftssüberung und Arbeitspflicht Anwendung:' Ibid., §18 i), 40. 50Ibid., §19 (1) a) -I) and (2), 46-50.

51Ludwig Haydn, ed., Das neue Nationalsozialistengesetz. Bundesverfassungsgesetz über die

Behandlung der Nationalsozialisten (Vienna, 1947), passim; see also Stiefel, Entnazifizierung, 101-24.

52See Gustav Hofmann and Franz Keller, eds., Das Arbeitspjlichtgesetz und die einschlügigen

Vorschriften, mit einge- henden Erlüuterungen und einem Sachregister (Vienna, 1946), §1 (2a) and §2 (1a).

In the Nationalrat, SPO delegate Wilhemine Moik emphasized that "the law foresees that National

Socialists will be drawn into reconstruction first and foremost"; Stenographische Protokolle der Sitzung des 
Nationalrates der Republik Osterreich (hereafter cited as Sten. Prot.NR), V. G.P., 8. Sitzung, 15 February 1946, 103. Moreover, in response to a curiously timed complaint from the Allies on the slow pace and organizational setbacks surrounding exploitation of the manual labor of Ehemalige dated 11 March 1946well after the Nationalrat had approved the Arbeitspflichtgesetz and sent it on to the occupation authorities for their imprimatur-the Austrian federal government officially replied in the very same words Moik had employed . See Stiftung Bruno Kreisky Archiv (hereafter cited as StBKA)-Ministerratsprotokolle, "Verhandlungs- schrift Nr. 16 über die Sitzung des Ministerrates am 9. April 1946;' 2-4. 53 Sten.Prot.NR, V.G.P.,8.Sitzung,15February1946,103.

54Hofmann and Keller, eds., Das Arbeitspflichtgesetz, §4-§6.

55 Archiv der Republik!Bundesministerium für Handel und Wiederaufbau (hereafter cited as AdR/BMfHW), 57.009/III/11/1946, "Kundmachung des Bundesministeriums für Handel und Wiederaufbau vom 23. Aprill946 übcr die Feststellung der fur die Arbeitspflicht zugdassenen Arbeitcn: Categories $\mathrm{A}$ through $\mathrm{C}$ received equal priority, and within $\mathrm{B}$ and $\mathrm{C}$ emphasis depended upon local and regional needs. Once these three categories had been sufficiently addressed, additional energy could be placed on categories D through G, weighted according to priority. Maisel).

56 Sten.Prot.NR, V. G.P., 8. Sitzung, 15 February 1946, $92-93$ (Friedrich Hillegeist), and 95 (Karl

57See Hofmann and Keller, eds., Das Arbeitspflichtgesetz, §5 (2), (4) and §9 \{1), (6), respectively. Interestingly, those who had been wounded while serving in the Third Reich's armed forces found themselves free from Arbeitspjlicht- unless those soldiers had become Nazis and had not been debilitated as a result of their injuries.

58 See "Verordnung des Bundesministeriums fur soziale Verwaltung vom 20. Mai 1946, uber arbeitsrechtliche Durchführungsbestimmungen zum Arbeitspftichtgesetz (Arbeitspftichtverordnung) BGBL Nr. 100;' §6 (1) and §12 (1), in Hofmann and Keller, eds., Das Arbeitspjlichtgesetz, 13 and 15, respectively. 59Archiv der Republik/Bundesministerium fur soziale Verwaltung (hereafter cited as AdRIBMfsV)

58.048- III/7/1946. See AdR!BMfsV 44.875-III/7/1946, Landesarbeitsamt Wien, Geschüftszahl 3.310/II/46 Dr. St/La, 8. August 1946, an das BMfsV-"Arbeitspflichtgesetz; Berichterstattung über die Erfahrung bei der Durchfuhrung:'

60WrStLA, Nachlass Korner, 4. Amtsführung 1945-51; 4.19 Polizeidirektion Wien,

Wochenberichte, November 1945-November 1946. See, for example, 4.19.22.: Wochenbericht fur die Zeit vom 14. bis 20. April 1946, "Razzia im Katfee Klinik, IX., Spitalgasse 2 am 17. April"; 4.19.23.:

Wochenbericht für die Zeit vom 21. bis 27. April 1946, "Razzia im Karntner Kino am 18. April;' in which 90 people were arrested and 20 assigned to work details; 4.19.24.: Wochenbericht vom 28. April bis 4. Mai 1946, "Razzia in den Gast- und Katfeehausern des IV. Bezirkes am 25. April;' in which all 36 people taken into custody were later assigned labor service; 4.19.25: "GroBrazien im mehreren Gast- und

Vergnügungsstatten des XIV. und XV. Bezirkes am 2. Mai;' in which 291 people were cited and 85 led off to clear rubble; 4.19.28., Wochenbericht fur die Zeit vom 26. Mai bis 1. Juni 1946: 260 people were

detained by Soviet troops

during a raid against black marketers at the Resselpark and 30 obliged to work.

61WrStLA-MD A6 Box 7, BA 892/46, "Josef H. an Herrn Bürgermeister Gen. Korner," 12 April 1946.

62Ibid., "Antos an Herrn Josef H., 19 April 1946.

63WrStLA-MD A1 Box 642, MD 1844/46.

64WrStLA-MD AI Box 644, MD 2221/46, 13 August 1946.

65Ibid., letter of 27 September 1946.

66WrStLA-MD A1 Box 645, MD 2621/46, note of 15 October 1946.

67WrStLA, Nachlass Korner, 4. Arntsführung, 1945-51; 4.14. Schuttbeseitigung, Wochenberichte

April-November 1946, 4.14.1. See Wiener Magistrat der Stadtbaudirektion, BD-2390/46.

68See, for example, WrStLA, Nachlass Korner, 4. Arntsführung, 1945-51; 4.19. Polizeidirektion

Wien, Wochenberichte,November 1945-November 1946, 4.19.14. Wochenbericht fur die Zeit vorn 18. bis

24. Februar 1946, "Unfalle."

69Ibid., 4.14.2. (10 April1946)-4.14.33. (10 November 1946).

70 Statistics released in January 1946, corresponding to the ten months following the collapse of the Third Reich, indicated 84,069 men and women available for work as Arbeiterlnnen or Angestelltlnnen and 121,825 vacant positions; 1946 figures released in January 1947 showed 68,225 people registered and 94,445 open positions; figures for the first three months of 1947, released at the end of March, recorded 
73,349 registered and 116,327 openings. See Osterreichisches fahrbuch (hereafter cited as OJ) (1945/46): 291.

71WrStLA-MD 1945-Arbeitseinsatz Nationalsozialisten bei Aufraumungsarbeiten, 1.178/45; Schneeraumung, 2.146(45; Schneesauberungsarbeiten, Heraziehung, 344/46.

72See, for example, WrStLA, Nachlass Korner, 4. Amtsführung, 1945-51; 4.19. Polizeidirektion

Wien, Wochen- berichte, November 1945-November 1946, 4.19.9.: "Selbstmord-die 40 Jahrige Rosa

Kirchner, Wien IX., Berggasse 14 wohnhaft, gewesen, üübergoss ihre Kleider mit Benzin, brachte diese in Brand, und stützte sich aus dem Fenster des 2. Stockes in den Lichthof, wo sie tot liegen blieb. Das Motiv der Tat ist der Verlust ihrer Wohnung bzw. Ihres Geschaftes wegen Zugehorigkeit zur NSDAP." 4.19.12.: "Selbstmord-der Bankbeamte Rudolf Sax wurde am 27. Janner 1946 in seiner Wohnung, Wien II., Ennsgasse 23, erhangt aufgefunden. Das Motiv dürfte die Zugehorigkeit zur NSDAP und die Kündigung seiner Anstellung in der Bank gewesen sein:

73See Dieter Stiefel, "Nazifizierung plus Entnazifi.zierung = Null? Bemerkungen zur besonderen Problematik der Entnazifizierung in Osterreich," in Verdrangte Schuld, verfehlte Sühne, ed. Meiss!, Mulley, and Rathkolb, 35; as well as Klaus-Dieter Mulley, "Zur Entnazifizierung der osterreichischen Wirtschaft," in Verdrüngte Schuld, verfehlte Sühne, ed. Meissel, Mulley, and Rathkolb, 100-128, for a broad overview of denazification in the public and private economic sectors between 1945 and 1947.

74Ernst Koref's insistence that "the staatspolitische re-schooling of fellow-travelers and the misled, who through earlier circumstances of historical experience have recognized the criminal content of Nazi fascism and of the war unleashed by it, succeed best and most methodically [when they] are gradually integrated into cooperation in society and state; is representative of the SPO focus upon the reintegration of Ehemalige through reeducation. See Sten.Prot. NR, V. G.P., 28. Sitzung, 24 July 1946, 595.

75In their comments on the published text of the Arbeitspflichtgesetz, Bundesministerium fur soziale Verwaltung officials Gustav Hofmann and Franz Keller remarked: "In closing, a feature of the law must be referred to yet again, one which points to a very important problem that was continually emphasized in the parliamentary negotiations- namely, the pressing necessity to not only put unemployed young people to work in the interest of the economy, but above all for educational reasons, for otherwise the gravest danger would emerge that a part of the youth would be completely lost for established work as a consequence of the grave educational transgressions of the National Socialist regime and as a result of the absence of selfrestraint and lack of willingness to work provoked by the war. Thus, [the law foreseesJ a possibility of creating a special educational institution in the form of commwullabor via the introduc- tion of young people into the work process." Hofmann and Keller, eds., Das Arbeitspflichtgesetz, 23.

76AdR/BMfsV 45.840-III/7/1946, Landesarbeitsamt Tirol, Geschüftszeichen 5.552, 10 August 1946, an das BMfSV- Arbeitspflichtgesetz; Berichterstattung über die Erfahrungen bei der Durchführung;' 3.

77AdR/BMfsV 44.057-III/7/1946. Landesarbeitsamt Vorarlberg, Geschüftszeichen IIa 5.109/5.552, 7 August 1946, an das BMfsV-Arbeitsptlichtgesetz; Durchführung des Arbeitsptlichtgesetzes:' 4. AdR/BMfsV 45.840-III/7/1946, Landesarbeitsamt Oberosterreich, Geschüftszeichen I (A) 1.958/46, 7 September 1946, an das BMSV-' rbeits- ptlichtgesetz; Berichterstattung über die Erfahrungen bei der Durchführung;' 1-2. Authorities in the industrial town of Steyr recorded fourteen arrests in connection with attempted evasion of Arbeitspflicht. AdR/BMfsV 44.875-III/7/1946, Landesarbeitsamt Niederosterreich, Geschaftszeichen Ila/5.552, 8 August 1946, an das BMfsV; 'rubeitsptlichtgesetz; Berichterstattung tiber die Erfahrungen bei der Durchführung," 1-2. Most of the local Lower Austrian Arbeitsamter reported strong resistance to mobilization for labor service, as the population equated the obligation with wartime compulsion. Arbeitsamter throughout the province expressed reluctance to introduce punitive measures.

78AdR/BMfsV 58.048-III/7/1946. Landesarbeitsamt Steiermark, Geschüftszeichen 5.552/Dr. Bi/Se., 28 September 1946, an das BMfsV-"Arbeitsptlichtgesetz; Berichterstattung über die Erfahrung bei der Durchführung;' 1; AdR/ BMfsV 44.875-II/7/1946, Landesarbeitsamt Niederosterreich, 3.

79AdR/BMfsV 51.936-III/7/1946. Landesarbeitsamt Karnten, Geschüftszeichen 4.030 Fr./Ha., 4 September 1946, an das BMfsV-Arbeitspflichtgesetz: Berichterstattung über die Erfahrungen bei der Durchführung, 1. Even after rati- fication of more stringent denazification legislation in 1947 that required former Nazis to engage in labor service (in the case of the "heavily implicated;' internment from six months to two years in labor detention camps was possible if said individuals were deemed dangerous to the security of Austrian democracy), no significant number of Ehemalige found themselves working under such conditions. See Article IV, $§ 18$ (j\}, in Das neue Nationalsozialistengesetz, ed. Haydn, 42; as well as US deputy to the Council of Foreign Ministers John G. Erhardt's dispatch to the US Secretary of State on the new denazification law of 1947, 7 January 1947 (prepared by Martin F. Herz\}, in Understanding 
Austria, ed. Wagnleitner, 100.

80For an elaboration of these positions, see AdRJBMfsV 72.390-III/8a/1946; AdR/BMfsV 83.202III/7/1946; AdRJBMfsV 122.945-III/9/1947; AdRJBMfsV 122.945-III/9/1947; AdR!BMfsV 135.091Juli/9/1947; and AdRJBMfsV 140.991-III/9/1947.

81AdRJBMfsV 122.945-III/9/1947. According to §18 (j) of the Verbotsgesetz, "(Former Nazis] can be exhorted to do compulsory work in accordance with the determinations of a special federal law." See Praeger, ed., Das Nationalsozi-alistengesetz, 40. Praeger was a legal scholar associated with the Arbeiterkammer in Vienna.

82See Haydn, ed., Das neue Nationalsozialistengesetz, 19.

83Stiefel, Entnazifizierung, 308-9.

84The United States provided almost 75 percent of total United Nations Relief and Rehabilitation Administration food relief; Great Britain contributed approximately 17 percent, and the remaining approximately I 0 percent was furnished by Canada, Australia, New Zealand, South Africa, Brazil, India, and other states. Recipient countries included Germany, Austria, Czechoslovakia, Poland, and the Soviet Union. UNRRA aid did not begin to reach Austria until April1946, almost a full year after liberation. See Wilfried Mahr, Der Marshall-Plan 111 Osterreich (Graz, 1989\}, 29ff. See also OJ (1945/46): 87-91. 85Aian S. Milward, The Reconstructiol1 of Western Europe, 1945-1951 (Berkeley, 1984\}, 103, table 19. See also AJois Brusatti, "Entwicklung der Witischaft und Wirtschaftspolitik;' in Osterreich: Die Zweite Republik, ed. Erika Weinzierl and Kurt Skalnik, val. 1 (Graz, 1972\}, 434-43. For a comprehensive examination of the ERP in Austria, see Gunter Bischof, Anton Pelinka, and Dieter Stiefel, eds., 1he Marshall Plan in Austria (New Brunswick, 2000\}. According to the Osterreichische Staatsdruckerei/Bundespressedienst publication Zehn Jahre ERP in Osterreich 1948/1958 (Vienna, 1958), 33, raw tonnage of aid delivered broke down as follows: foodstutfs-793,234 tons; agricultural machines and appliances-9,877 tons; pesticides-4,917 tons; animal feed-5,078 tons; fertilizers-74,171 tons; crop seed (net)- 74,953 tons; miscellaneous industrial supplies-2,465 tons; textiles-3,117 tons; raw materials-129,971 tons; medical supplies-1,195 tons; vehicles-1,195 pieces; trailers for vehicles-233 pieces.

86Direct assistance totaled \$211 million in 1948/49, \$168 million in 1949/50, and \$38.4 million between 1 July and 31 December 1950; indirect aid carne to $\$ 66.6$ million in 1948/49, \$85.8 million in 1949/50, and \$80 million in 1950/51. See Zehn Jahre ERP, 94.

87The Belasteten were reintegrated with the 1957 amnesty legislation, which included: BGBI Nr 82/1957, Bundesver-fassungsgesetz vom 14. Mürz 1957 womit Bestimmungen des

Nationalsozialistengesetzes BGBI. Nr. 25/1947, abgeündert oder aufgehoben werden; BGBI. Nr. 83, Bundesgesetz vom 14. Mürz 1947 uber eine Amnestie fur politische Straftaten (Amnestie 1957); and BGBI. Nr. 123/1957, Verordnung der Bundesregierung vom 4. funi 1957 zur Durchfuhrung der NS-Amnestie 1957.

88Mahr, Der Marshall-Plan in Osterreich, 46-47; Fritz Weber, Der kalte Krieg in der SPO.

Koalitionswüchter, Pragmatiker und revolutionüre Sozialisten 1945-1950 (Vienna, 1986), 120-22.

89Günter Bischof, "'Conquering the Foreigner': The Marshall Plan and the Revival of Postwar

Austrian Tourism," in The Marshall Plan in Austria, ed. Bischof, Pelinka, and Stiefel, 365-66. Italics

in the original. Only 6 percent of that 19 percent reached Vienna. Ibid., 386, table 3.

90Approximately 63 percent of all destruction wrought by the war had occurred in Vienna,

according to an Austria - wide inquiry conducted by Ministry of Trade and Reconstruction officials.

Magistral der Bundeshauptstadt Wien, ed., Verwaltungsbericht vom 1. April1945 bis 31. Dezember 1947, 235.

91WrStLA-MD A9 Box 4, AV 260/46, "M.Abt. 25-Schuttak:tion an den Herrn Bürgermeister;· 25

August 1946, 1.

92WrStLA-Nachlass Korner: 4. Amtsführung, 1945-1951, 4.14 Schuttbeseitigung, Wochenberichte. 93WrStLA-MD A9 Box 4, AV 260/46, "M.Abt. 25-Schuttaktion an den Herrn Bürgermeister," 25

August 1946, 1.

94Ibid., 3.

95Magistrat der Bundeshauptstadt Wien, ed., Verwaltungsbericht vom 1. Apri/1945 bis 31.

Dezember 1947, 219.

96Ibid. See also "Die Wiederautbau im ersten Halbjahr 1946;' in Amtsblatt der Stadt Wien 51, no.

31/32 (28 August: 1946): 1-3.

97WrStLA-MD Al Box 688, MD 563/49, "Ktr.A.I.-2912/48: NS-Registrierungsstellen,

Arbeitsumfang und Personalstand an die Magistratsdirektion;' 16 December 1948. The 125,604 Ehemaligen 
required to register represented just over 10 percent of Vienna's population as reflected in initial postwar municipal population estimates reported in June 1945 in conjunction with census calculation and Soviet food aid delivery. See WrStLA-MD A1 Box 623, MD 204/45, 2 June 1945.

Matthew Paul Berg is Associate Professor of History at John Carroll University. The author would like to thank Julia Karolle for her comments and criticism through various drafts of this article, Nicole Phelps for her editorial assistance, and the anonymous reviewers for their helpful suggestions. 